\title{
Knowledge and Attitude toward Denture Adhesives: A Survey on Dentists and Complete Denture Wearers
}

\author{
${ }^{1}$ Rupal J Shah, ${ }^{2}$ Sanjay B Lagdive, ${ }^{3}$ Arun Kumar Talkal, ${ }^{4}$ Hemal Agrawal, ${ }^{5}$ Bhavyata Darji
}

\begin{abstract}
Aims and objectives: The objective of the study was to investigate the attitude and assess to the knowledge of complete denture wearers and dentists toward denture adhesive and to initiate awareness for the same.
\end{abstract}

Materials and methods: A questionnaire was mailed to 850 dentists out of which 456 dentists replied. Three hundred and sixty-two complete denture wearers were surveyed with a different questionnaire in the department and were assessed for awareness and usage of denture adhesive.

Results: The results of this survey indicated that $66.89 \%$ of dentists used denture adhesives in their practice. Complete denture wearers lack awareness regarding use of denture adhesives as $74.5 \%$ of them had never tried denture adhesives. Majority of dentists are also unfamiliar with their beneficial effects.

Conclusion: It should be emphasized that denture adhesives can be considered as a beneficial adjunct to improve fit, comfort, and function of dentures, and psychological security of patients when indicated in schools of dentistry. The knowledge of the patients will always depend on the knowledge of the dentists and how well the dentists educate their patients.

Key message: The outcome of this survey demonstrates that the rate of knowledge of dental practitioners and patients toward denture adhesives has not been in a good situation.

Keywords: Attitude, Complete dentures, Denture adhesives, Knowledge, Questionnaire.

How to cite this article: Shah RJ, Lagdive SB, Talkal AK, Agrawal H, Darji B. Knowledge and Attitude toward Denture Adhesives: A Survey on Dentists and Complete Denture Wearers. Int J Prosthodont Restor Dent 2015;5(3):74-80.

Source of support: Nil

Conflict of interest: None

\section{INTRODUCTION}

A main goal of prosthetic treatment is to restore masticatory function. ${ }^{1}$ Along with it, improving denture

\footnotetext{
${ }^{1}$ Head, ${ }^{2}$ Professor, ${ }^{3}$ Postgraduate Student

${ }^{4}$ Assistant Professor, ${ }^{5}$ Tutor

${ }^{1-5}$ Department of Prosthodontics, Government Dental College and Hospital, Ahmedabad, Gujarat, India
}

Corresponding Author: Arun Kumar Talkal, Postgraduate Student, Department of Prosthodontics, Government Dental College and Hospital, Ahmedabad, Gujarat, India, Phone: 7405373319, e-mail: arunkumartalkal@gmail.com retention and stability has always been major challenge in prosthodontics. ${ }^{2}$ Retention, stability and support of denture can be augmented by using denture adhesives which on absorbing saliva swell up and create a strong hold between dentures and the underlying tissues. ${ }^{3}$

Thus, this study is done to investigate the thought and approach of complete denture wearers toward denture adhesives and to know the reason for their trial of denture adhesives and also the cause for continuation of its use through a questionnaire, it also investigates the usage of denture adhesives by dentists and undergraduate students as their attitude, knowledge and experience toward it is still unclear.

\section{MATERIALS AND METHODS}

A dentist and patient questionnaire was first prepared and tested by the faculty members of prosthodontia department. An online survey consisting of the tested and corrected multiple choice questionnaire was framed regarding some basic knowledge about denture adhesives. The survey links were then sent to 850 dental practitioners who were asked to record their responses.

The number of questions were 14 out of which not all were mandatory and few had an option to choose multiple answers. An additional provision for writing specific comments was also provided for some of the questions (Table 1).

Following a reminder e-mail to those who had not responded, 456 practitioners replied, yielding a response rate of $53 \%$.

Patient's attitude regarding usage of denture adhesives was checked using a prepared questionnaire (Table 2).

Three hundred and sixty-two edentulous patients (215 males and 147 females) wearing complete dentures were selected. Patient's consent and approval were obtained for their participation in the study. Demographic data and denture related history were obtained.

The results were prepared in graphs. Percentage evaluation was done for the responses obtained. This data formed the basis for the assessment.

\section{RESULTS}

The overall response rate of the survey was 53\% with a total of 456 responses. All percentages in this article are rounded to the nearest whole number. 
Table 1: Original dentists questionnaire

\begin{tabular}{|c|c|c|c|c|}
\hline Question & $A$ & $B$ & C & $D$ \\
\hline $\begin{array}{l}\text { 1. Do you prescribe denture adhesives } \\
\text { to your patients when indicated? }\end{array}$ & Yes & Sometimes & Never & \\
\hline $\begin{array}{l}\text { 2. Which type of denture adhesive do } \\
\text { you prefer to prescribe? }\end{array}$ & Powder & Cream & Pads or strips & Other \\
\hline $\begin{array}{l}\text { 3. Which of the following constituents } \\
\text { are commonly found in most denture } \\
\text { adhesives? }\end{array}$ & Silicone & $\begin{array}{l}\text { Carboxymethyl } \\
\text { cellulose }\end{array}$ & Polysulfide & Polyvinyl siloxane \\
\hline $\begin{array}{l}\text { 4. Do you know the mechanism of action } \\
\text { of denture adhesives? }\end{array}$ & $\begin{array}{l}\text { Increasing the } \\
\text { viscosity }\end{array}$ & $\begin{array}{l}\text { Decreasing the } \\
\text { viscosity }\end{array}$ & None & \\
\hline $\begin{array}{l}\text { 5. Do you use denture adhesives in your } \\
\text { practice? }\end{array}$ & Yes & Sometimes & Never used & \\
\hline $\begin{array}{l}\text { 6. Denture adhesives are used during } \\
\text { which stage of denture fabrication? }\end{array}$ & Do not use & $\begin{array}{l}\text { Used for stabilizing trial } \\
\text { base during jaw relation }\end{array}$ & $\begin{array}{l}\text { Used for stabilizing } \\
\text { trial base during } \\
\text { try-in }\end{array}$ & $\begin{array}{l}\text { Used during } \\
\text { denture delivery }\end{array}$ \\
\hline $\begin{array}{l}\text { 7. Which of the following benefits are } \\
\text { not associated with the use of } \\
\text { denture adhesives? }\end{array}$ & $\begin{array}{l}\text { Reduced food debris } \\
\text { accumulation beneath } \\
\text { the denture base }\end{array}$ & $\begin{array}{l}\text { Improved chewing } \\
\text { efficiency }\end{array}$ & $\begin{array}{l}\text { Improved } \\
\text { coloration of the } \\
\text { denture base } \\
\text { material }\end{array}$ & $\begin{array}{l}\text { Reduced mucosal } \\
\text { irritation }\end{array}$ \\
\hline $\begin{array}{l}\text { 8. Do denture adhesives improve masti- } \\
\text { cation and phonation in denture } \\
\text { wearers? }\end{array}$ & Yes & May be & Do not know & \\
\hline $\begin{array}{l}\text { 9. Can excessive use of zinc containing } \\
\text { denture adhesive cause neurological } \\
\text { disease? }\end{array}$ & Yes & May be & Do not know & \\
\hline $\begin{array}{l}\text { 10. What are the advantage of } \\
\text { prescribing well-hydrated denture } \\
\text { adhesive for xerostomic complete } \\
\text { denture patient? }\end{array}$ & $\begin{array}{l}\text { Facilitates } \\
\text { cleansibility of the } \\
\text { denture }\end{array}$ & $\begin{array}{l}\text { Increases frictional } \\
\text { stability of the } \\
\text { prosthesis }\end{array}$ & $\begin{array}{l}\text { Provides a } \\
\text { cushioning or } \\
\text { lubricating effect }\end{array}$ & $\begin{array}{l}\text { Permits ease } \\
\text { of prosthesis } \\
\text { placement and } \\
\text { removal }\end{array}$ \\
\hline $\begin{array}{l}\text { 11. What can improper use of denture } \\
\text { adhesives cause? }\end{array}$ & $\begin{array}{l}\text { Imbalance in oral flora } \\
\text { leukoplakia }\end{array}$ & $\begin{array}{l}\text { Alveolar bone resorption } \\
\text { oral cancer }\end{array}$ & Candidiasis & Denture stomatitis \\
\hline $\begin{array}{l}\text { 12. State your opinion regarding denture } \\
\text { adhesives }\end{array}$ & Increases the fitness & $\begin{array}{l}\text { Provides psychological } \\
\text { comfort to patients }\end{array}$ & $\begin{array}{l}\text { Masks all } \\
\text { underlying denture } \\
\text { problems }\end{array}$ & $\begin{array}{l}\text { Contributes to } \\
\text { avoiding dental } \\
\text { visits }\end{array}$ \\
\hline
\end{tabular}

Table 2: Original patients questionnaire

\begin{tabular}{|c|c|c|c|c|}
\hline Question & $A$ & $B$ & $C$ & $D$ \\
\hline $\begin{array}{l}\text { 1. When have you tried using denture } \\
\text { adhesive? }\end{array}$ & Never tried & $\begin{array}{l}\text { Tried atleast } \\
\text { once }\end{array}$ & Use regularly & \\
\hline 2. Who has indicated you denture adhesive? & Dentist & By myself & Friend & $\begin{array}{l}\text { Another } \\
\text { answer }\end{array}$ \\
\hline $\begin{array}{l}\text { 3. What type of denture adhesive have you } \\
\text { tried? }\end{array}$ & Powder & Cream & Pads/strips & \\
\hline 4. How long have you used denture adhesive? & Until 1 month & 1 to 6 months & 6 months to 1 year & $\begin{array}{l}\text { Another } \\
\text { answer }\end{array}$ \\
\hline $\begin{array}{l}\text { 5. Did the performance of your denture } \\
\text { improve? }\end{array}$ & It improved a lot & It improved little & It did not improve & \\
\hline $\begin{array}{l}\text { 6. What was most unpleasant when you were } \\
\text { using denture adhesive? }\end{array}$ & Taste & Consistency & Difficulty in removal & $\begin{array}{l}\text { Another } \\
\text { answer }\end{array}$ \\
\hline $\begin{array}{l}\text { 7. How do you clean your dentures with denture } \\
\text { adhesives? }\end{array}$ & $\begin{array}{l}\text { Placing them under } \\
\text { running water }\end{array}$ & $\begin{array}{l}\text { Scrubbing with } \\
\text { denture brush }\end{array}$ & $\begin{array}{l}\text { Cleaning with a cotton gauze } \\
\text { and then rinse under hot water }\end{array}$ & $\begin{array}{l}\text { Another } \\
\text { answer }\end{array}$ \\
\hline $\begin{array}{l}\text { 8. Are you overall satisfied with the use of } \\
\text { denture adhesive? }\end{array}$ & Yes & For sometime & Not really & \\
\hline
\end{tabular}

A total of $27.1 \%$ (127) of respondents were postgraduates, while $72.9 \%$ (329) were undergraduates.

With regards to the prescription, $270(59.38 \%)$ prescribed denture adhesives, $160(35.10 \%)$ prescribed it sometimes while $26(5.25 \%)$ never prescribed it (Graph 1).
In regards to the type $321(71.81 \%)$ preferred adhesive in powder form, $209(46.76 \%)$ in cream form, $34(7.61 \%)$ preferred adhesives in the form of pads or strips while $1(0.22 \%)$ specified gel.

Out of the given four choices in regards to the most common constituent in denture adhesive, 31 (7.06\% 
said silicone was found the most, majority 354 (80.64\%) said carboxy methyl cellulose was the most common constituent, 32 (7.29\%) said polysulfide while 22 (5.01\%) said polyvinyl siloxane.

Maximum 267 (60.82\%) dentists said that denture adhesives worked by the mechanism of increasing the viscosity of saliva, 114 (25.97\%) said by decreasing the viscosity of saliva while 58 (13.21\%) denied with any of the choices given.

Out of 444 responses, 104 (23.42\%) used denture adhesives in their practice, 297 (66.89\%) sometimes used it while $43(9.68 \%)$ never used denture adhesives in their practice.

Three hundred and one (67.04\%) used denture adhesives for stabilizing trial bases during jaw relation, $280(62.36 \%)$ used it for stabilizing trial bases during tryin, 178 (39.64\%) used during denture delivery (Graph 2).

Ninety-two (20.63\%) claimed that denture adhesives do not reduce food debris accumulation beneath the denture base, 100 (22.42\%) thought it does not improve chewing efficiency, $337(75.56 \%)$ were against the point

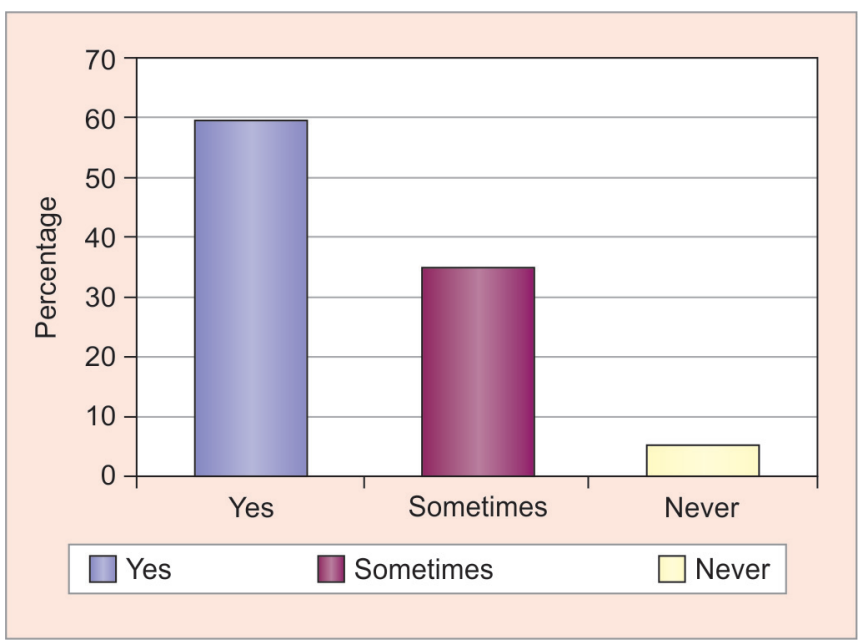

Graph 1: Do you prescribe denture adhesive to your patients when indicated?

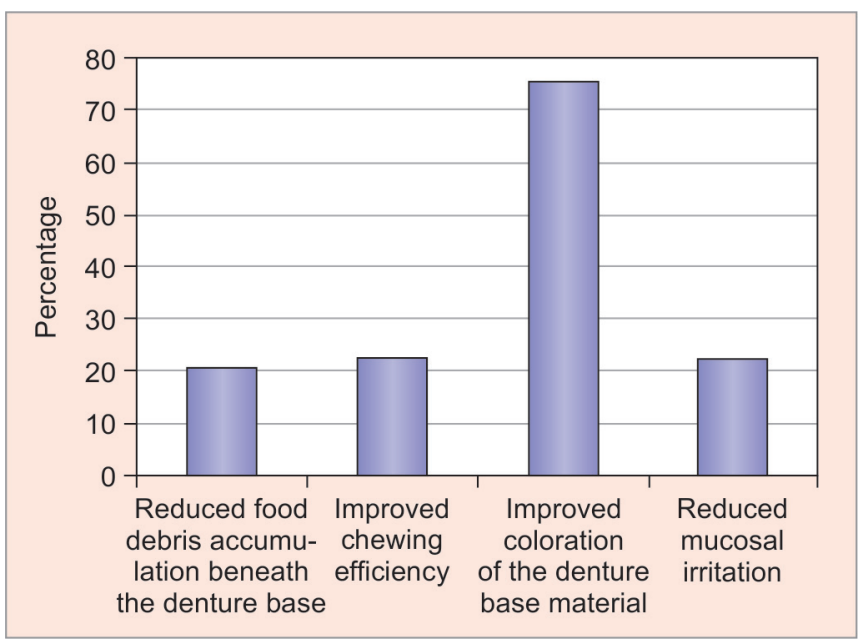

Graph 3: Which of the mentioned benefits are not associated with the use of denture adhesives? that it improves coloration of the denture base material while $100(22.42 \%)$ said that it does not reduce mucosal irritation (Graph 3).

Two hundred and twenty (48.78\%) of the dentists accepted that denture adhesives improve mastication and phonation in denture wearers. One hundred and eighty-nine (41.91\%) thought it may be improved these qualities while the rest 42 (9.31\%) did not know about it.

Majority 160 (36.04\%) of the dentists did not know that zinc containing denture adhesives caused neurological disease or not. Whereas 144 (32.43\%) said knew about it while $140(31.53 \%)$ of them were not sure about it (Graph 4).

According to 110 (24.61\%) dentists, if xerostomic patients used well hydrated denture adhesives it would be advantageous as it facilitates cleansibility of the denture, $264(59.06 \%)$ said it increases frictional stability of the prosthesis, $248(55.48 \%)$ said it provides a cushioning or lubricating effect while $122(27.29 \%)$ said it permits ease of prosthesis placement and removal.

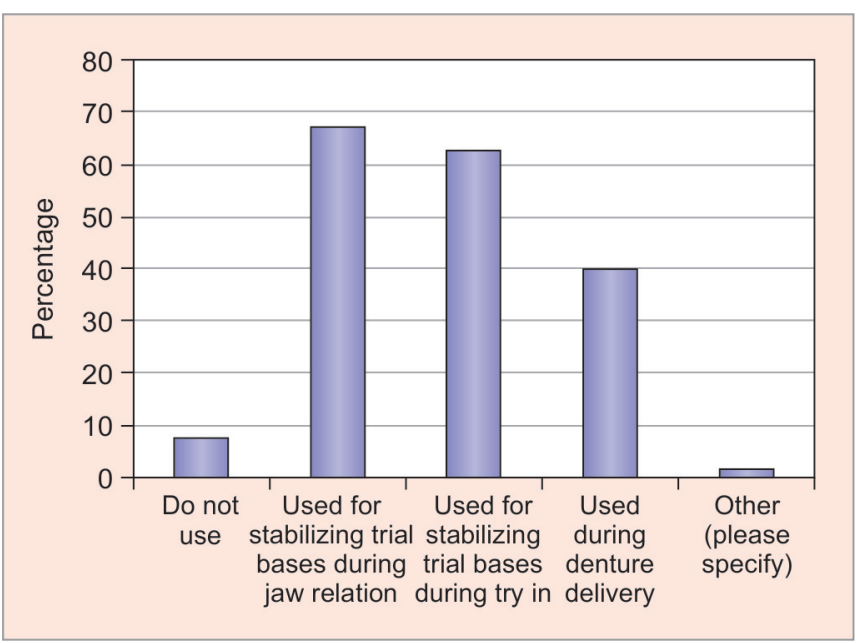

Graph 2: Denture adhesives are used during which steps of denture fabrication?

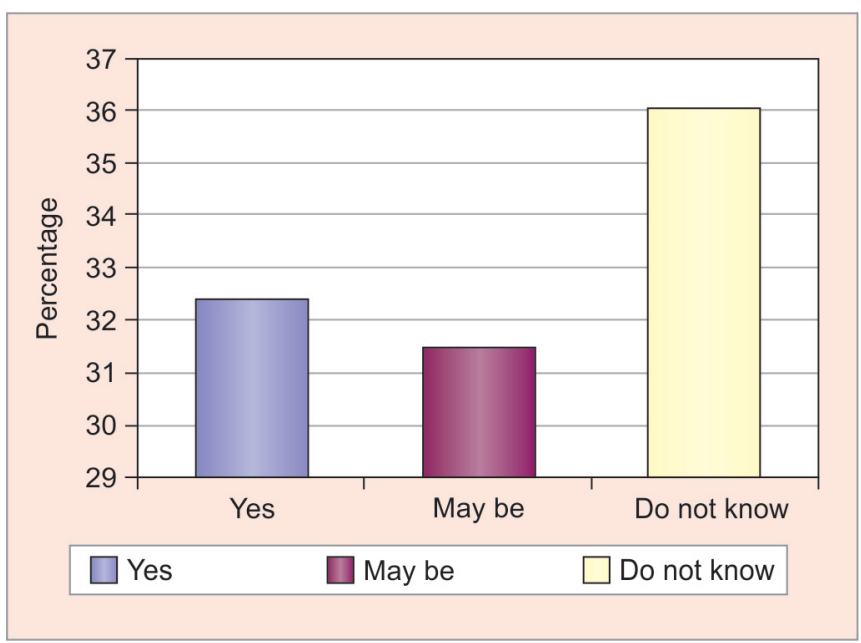

Graph 4: Can excessive use of zinc containing denture adhesives cause neurological disease? 
According to this survey, 178 (39.73\%) dentists said that improper use of denture adhesives causes imbalance in oral flora, $172(38.39 \%)$ think it may cause alveolar bone resorption, $224(50.00 \%)$ maximum said it could cause candidiasis, $242(54.02 \%)$ responded denture stomatitis, $65(14.51 \%)$ responded leukoplakia while 66 (14.73\%) responded oral cancer (Graph 5).

A total of $258(57.21 \%)$ used denture adhesives because it increases the fitness, $351(77.83 \%)$ responded it provides psychological comfort to the patients, 87 (19.29\%) responded it masks all underlying denture problems, while according to $99(21.95 \%)$ dentists it contributes in avoiding dental visits (Graph 6).

A total of 362 patients were included in the study. There were 215 males and 147 females. The mean age of patients was 63 years.

Two hundred and seventy $(74.5 \%)$ patients reported that they had never tried denture adhesives. Fifty $(13.8 \%)$ denture wearers had used denture adhesives in the past for improving the retention and stability of their dentures but none of them were currently using it and $42(11.6 \%)$ use it on regular basis.

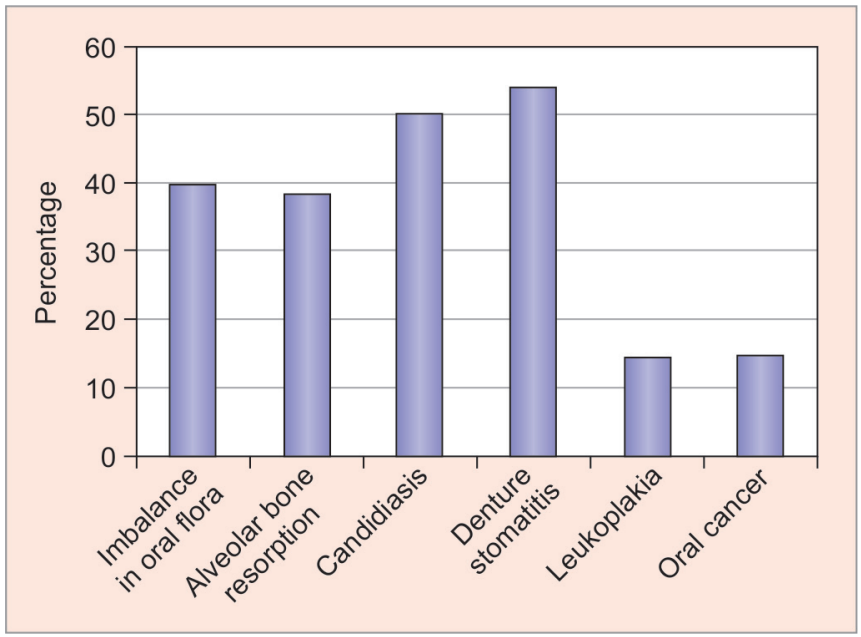

Graph 5: What can improper use of denture adhesives cause?

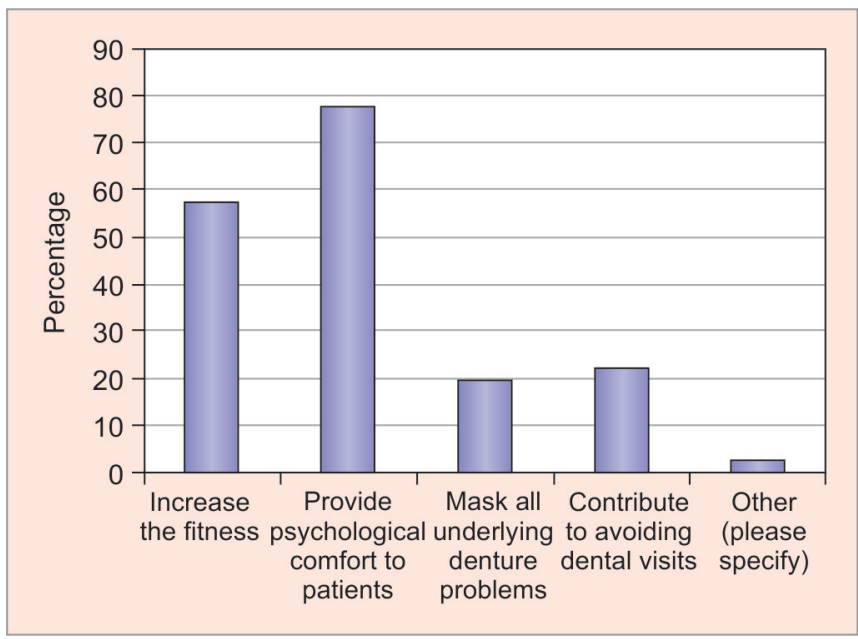

Graph 6: State your opinion regarding denture adhesives
Sixty-two (67\%) informed it was indicated by a dentist, $17(18.4 \%)$ have used by themselves, $13(14.1 \%)$ informed it was indicated by a friend.

Out of all, majority $70(76 \%)$ used adhesives in powder form, $10(10.8 \%)$ used it in cream form while two $(2.1 \%)$ used pads/strips.

Twenty-four (26.1\%) used it until 1 month, 28 (30.4\%) used it from 1 to 6 months while 40 (43.4\%) used from 6 months to 1 year.

According to $24(26.1 \%)$ of the respondents, the performance of their dentures improved a lot after the use of denture adhesives; for 48 (52.17\%) of them, it improved a little while 20 (21.7\%) indicated that it did not improve.

Among the participants that have ever used adhesives, for $30(32 \%)$ denture wearers taste and for $47(51.1 \%)$ of them consistency were the most cited complaints, but 15 $(16.3 \%)$ mentioned difficulty of removal from oral tissues and dentures.

Thirty-five (38\%) cleaned their denture of denture adhesives by placing them under running water, $25(27.1 \%)$ scrubbed it with a denture brush while 32 (34.7\%) clean it with a cotton gauze, and then rinse under hot water.

Forty-two (45.6\%) of the patients were satisfied after using denture adhesives, $37(40.2 \%)$ said for sometime it improved while $13(14.1 \%)$ were not really satisfied.

\section{DISCUSSION}

A comment often made by patients who have problems with their natural dentition is, 'take them all out and give me dentures so that I will not have any more dental problems. Often denture patients, rather than seeking professional help to evaluate oral changes affecting denture function, will turn to some type of denture adhesive to achieve the desired function and comfort.

According to Zarb and Boucher, there are several factors responsible for retention of complete dentures which include adhesion, cohesion, interfacial surface tension, capillary action, atmospheric tension and facial musculature. These factors, along with proper fabrication of the complete denture, contribute to retain the prosthesis. Denture adhesives act as an adjuvant to increase denture retention and stability, and various research studies suggest that its use significantly decreased displacement of mandibular and maxillary dentures during chewing, biting and speaking. ${ }^{4-7}$

This survey was an effort to clarify the various topics on denture adhesive. Such information could be useful for both the dental professionals and dental patients by presenting opinions and beliefs on the topic of denture adhesives.

In our survey, 104 (23.4\%) of all dentists used denture adhesives in clinical steps, 269 (59.3\%) dentists prescribed 
to their patients when indicated. Thus, it is concluded that majority dentists prescribe denture adhesives to their patients instead of using them during clinical steps. This is in contrast to a recent survey done in Turkey where $183(56.3 \%)$ of all dentists used denture adhesives in clinical steps, $136(41.8 \%)$ dentists prescribed to their patients when indicated; the number of dentists who prescribed denture adhesives was relatively less than the ones who used in clinical steps.

In this survey, denture adhesive is referred to a commercially available nontoxic, soluble material (powder, cream or liquid) that is applied to the tissue surface of the denture. According to old literatures and a recent survey; powder form in particular are readily available and the most effective over the counter materials and also they are proven to be used commonly by denture wearers. Fixon and fitty dent are the most common denture adhesive in powder form. This survey also yields the same conclusion where majority of the dentists 321 (71.81\%) use denture adhesive in powder form.

Shay ${ }^{8}$ prescribed the mechanism of action of adhesives in 1991. These materials swell 50 to $150 \%$ by volume in presence of water, filling the spaces between the prosthesis and the tissues. Saliva increases the viscosity of the adhesive thereby increasing the force required to separate the prosthesis from the tissue surface. Two hundred and sixty-two $(60.82 \%)$ knew the mechanism of action on denture adhesives.

The composition of most modern denture adhesives includes constituents that promote bioadhesion via carboxyl groups once the adhesive is hydrated. Two commonly employed active ingredients in denture adhesives are poly vinyl methyl ether maleate and carboxymethyl cellulose. The physical chemistry of these adhesive constituents is discussed in detail elsewhere. ${ }^{9-11}$ Once placed on the intaglio surface of the denture, the adhesive material must be substantially hydrated in order to achieve optimal performance.

Maximum utilization of denture adhesive by the dentists 301 (67.04\%) in their clinical practice was for stabilizing trial bases during recording jaw relations. This was consistent with the consensus were reached by the prosthodontists panel (88\%) in the study by Slaughter et al the reason being stable record bases is a prerequisite for recording accurate jaw relations.

After wearing the denture without adhesives, there was a marked deterioration in the articulation. This is in accordance with Banknson and Byrne ${ }^{12}$ who reported that loose dentures will not allow the tongue to function normally and this in turn will affect speech.

Nowadays, this philosophy was changed. The use of denture adhesives is highly recommended with patients seeking for extra retention demands that cannot be achieved by the routine protocol of complete denture fabrication. ${ }^{13}$ Denture retention and stability were significantly improved with the use of denture adhesives due to the bond created between the denture base and the underlying supporting tissues. ${ }^{14}$

The result of this study showed the positive influence of denture adhesive on masticatory function of denture wearers. According to Koronis et al, ${ }^{15}$ denture adhesive application increases the mastication ability in 66 to $70 \%$ of denture wearers. According to our results also, $220(48.78 \%)$ dentists agree with that denture adhesive significantly improvises mastication and phonation.

Of late, serious reports on the chronic and excessive use of $\mathrm{Zn}$ containing denture adhesive causing potential neurotoxicity have caught the attention of dental fraternity. ${ }^{16-18}$ Unfortunately, 36.04\% of the dentists were unknowledgeable about the adverse effect of $\mathrm{Zn}$ in denture adhesive.

Nations and Hedera et al, ${ }^{19,20}$ in their case series studies, identified misuses of $\mathrm{Zn}$ containing denture adhesive as the sole source of neurologic disease in patients using them. Recently, overuse of $Z$ n containing denture adhesive has been recognized as a potential cause of copper deficiency myelopathy. ${ }^{21}$ Recovery from neurological symptoms with replacement therapy appears to be limited and so emphasis falls on patient education on the use of denture adhesive. As a consequence; patients should be encouraged to seek professional advice before using such products and follow professional instructions carefully before using them.

Patients suffering from xerostomia are benefited by the use of well-hydrated denture adhesive as it provides a cushioning or lubricating effect, hence reducing functional irritation to the supporting soft tissues and in turn preventing further tissue dehydration and from denture stomatitis and ulcerations. ${ }^{10}$ In this study, 248 $(55.58 \%)$ dentists agreed with the above statement.

Slaughter et $\mathrm{al}^{22}$ stated that denture adhesives could contribute to the development of denture stomatitis, candidiasis, alveolar bone resorption and imbalance in oral flora, but not leukoplakia or oral cancer. Stafford et $\mathrm{al}^{23}$ indicated that denture adhesive could influence oral flora by causing an imbalance in the flora. Most of general dental practitioners (47\%) were ignorant that prolonged use of denture adhesive on ill-fitting dentures would result in residual ridge resorption. ${ }^{22}$ The prolonged use of ill-fitting dentures not only causes trauma to soft tissues, but also accelerates alveolar ridge resorption.

In this study, dentists consensus overcome $77.83 \%$ on this statement that mentioned denture adhesives are useful for providing a psychological relief to the denture patients and $19.29 \%$ stated adhesives also helps in masking underlying denture problems. Our results showed that 
it is agreed that denture adhesive be able to enhance the fitness of a denture and provide psychological relief to the patients.

In this study, a significant number of patients $(74.5 \%)$ had never used denture adhesives. This indicates that most of the patients are not well informed regarding this useful treatment modality. In a study by Coates, ${ }^{24}$ almost $33 \%$ of patients had tried denture adhesives but only $7 \%$ were currently using it. In another study conducted in Istanbul, $87 \%$ of patients did not know denture adhesives existed, $8 \%$ had tried denture adhesives but none of them continued it on a regular basis. ${ }^{25}$ Tarbet and Grossman ${ }^{26}$ stated that about $12 \%$ of the patients who wore a denture also used an adhesive. The outcome of the current study suggests that the knowledge of the patients is not enough probably because it is still generally believed by the practitioners that the prescription of a denture adhesive is a sign of failure of the dentist.

In a previous report, Ozcan et $\mathrm{al}^{25}$ surveyed 115 patients attending in Marmara University, Istanbul, Turkey, and observed that $92 \%$ had never tried denture adhesives. It has been shown that a substantial proportion of denture wearers had tried or currently used denture adhesives. ${ }^{25,27}$ Douglass et $\mathrm{al}^{28}$ stated that $22 \%$ of complete denture wearers in USA regularly use adhesives.

In this study, most participants that regularly used adhesives were satisfied with its performance, in accordance with previous reports. ${ }^{15,24,29}$

The most unpleasant factors concerning adhesives usage were taste and consistency, but difficulty of removal from oral tissues and dentures was also mentioned, in accordance with previous studies. ${ }^{24}$

Overall, the present study achieves its purpose by creating minor inroads into an otherwise unknown domain of use, misuse, conception, misconceptions, practice and malpractice of denture adhesives among the dentists in India. The results from the present study conclude that the knowledge about these dental materials is limited.

\section{CONCLUSION}

The general approach by the prosthodontists was that denture adhesives could be prescribed only when it was indicated. According to this survey, it can be determined that a positive change can be observed among the dentists and patients regarding the use of denture adhesives which is found to be in contradiction to various historical literatures. However, regardless of the fact that dentists nowadays use denture adhesives, it was observed that very few among them had sufficient knowledge regarding it.

In conclusion, based on the limitations of the subjective study for patients, it could be shown that the majority of the participants who had never tried denture adhesives showed refusal for the use of denture adhesives and the participants who had used denture adhesives on a regular basis, did have the knowledge of its efficacy. The knowledge of the patients will always depend on the knowledge of the dentists and how well the dentists educate their patients.

The attitude is a reflection of an individual's knowledge, which was also not homogeneous. If the knowledge about the use, efficiency and advantage of denture adhesives are taught more intensively in Indian dental schools then the practitioners can keep themselves updated regarding new technology and materials, thus, improving the standard of care for prosthodontic patients.

\section{REFERENCES}

1. Goncalves, et al. Denture adhesives improve mastication in denture wearers. Int J Prosthodont 2014;27(2):140-146.

2. Figueiral MH, et al. The effect of different adhesive materials on retention of maxillary complete dentures. Quintessence Publishing Co. Inc 2011;24(2):175-177.

3. Ahlawat P, Darki HA, Zahir Y, Saini D. Survey on availability and usage of denture adhesives in Malaysia: a preliminary study. Asian J Pharma Hea Sci 2012;2(1):286-289.

4. Hong G, Maeda T, Hamada T. The effect of denture adhesive on bite force until denture dislodgement using a gnathometer. Int Chin J Dent 2010;10:41-45.

5. Aziz EA, Aziz AA, Ibrahim DEE, Ahmed AEM. Comparative study between different adhesives in improving phonation in complete denture wearers. Am J Sci 2010;6(1):556-661.

6. Manes JF, Selva EJ, De-Barutell A, Bouazza K. Comparison of the retention strengths of three complete denture adhesives: an in vivo study. Med Oral Patol Oral Cir Bucal 2011 Jan;16(1): 132-136.

7. Hasegawa S, Sekita T, Hayakawa I. Effect of denture adhesive on stability of complete dentures and the masticatory function. J Med Dent Sci 2003 Dec;50(4):239-247.

8. Shay K. Denture adhesive, choosing the right powder and paste J. Am Dent Assoc 1991 Jan;122(1):70-76.

9. Kelsey CC, Lang BR, Wang RF. Examining patient's responses about the effectiveness of five denture adhesive pastes. J Am Dent Assoc 1997 Nov;128(11):1532-1538.

10. Shay K. The retention of complete dentures. In: Zarb GA, Bolender CL, Carlsson GE, editors. Boucher's prosthodontic treatment for edentulous patients, 11th ed. St Louis: MosbyYear Book Inc; 1997. pp. 400-411.

11. Grasso JE. Denture adhesives: changing attitudes. J Am Dent Assoc 1996 Jan;127(1):90-96.

12. Banknson N, Byrne $M$. The relationship between missing teeth and selected consonants sound. J Speech Hear Disorders 1962; 27:341-348

13. Batt C, Hof M, Zeghbroeck L, Ozcan M, Kalk W. An international multicenter study on the effectivness of a denture adhesive in maxillary dentures using a disposable gnathometers. Clin Oral Invest 2007;11:237-243.

14. Adisman I. The use of denture adhesives as an aid to denture treatment. J Prosthet Dent 1989;62:711-715.

15. Koronis S, Pizatos E, Polyzois G, Lagouvardos P. Clinical evaluation of three denture cushion adhesives by complete denture wearers. Gerodontol 2012 Jun;29(2):e161-e169.

16. Felton D, Cooper L, Duqum I, Misley G, Guckes A, Haugh S, Meredith $\mathrm{P}$, et al. Evidence based guidelines for the care and 
maintenance of complete dentures-a publication of the American College of Prosthodontics. J Prosthodont 2011;20:S1 S9-S12.

17. Lamb DJ. Denture adhesives: a side effect. J Dent 1980 Mar;8(1):35-42.

18. Zhao K, Cheng XR, Chao YL, LI ZA, Han GL. Laboratory evaluation of a new denture adhesive. Dent Mater 2004 Jun;20(5):419-424.

19. Nations SP, Boyer PJ, Love LA, Burritt MF, Butz JA, Wolfe GI, Hynan LS, Reisch J, Trivedi JR. Denture cream: an unusual source of excess zinc, leading to hypocupremia and neurologic disease. Neurology 2008;71(9):639-643.

20. Hedera P, Peltier A, Fink JK, Wilcock S, London Z, Brewer GJ. Myelopolyneuropathy and pancytopenia due to copper deficiency and high zinc levels of unknown origin IIthe denture cream is a primary source of excessive zinc. Neurotoxicology 2009;30(6):996-999.

21. Doherty K, Connor M, Cruickshank R. Zinc-containing denture adhesive: a potential source of excess zinc resulting in copper deficiency myelopathy. Br Dent J 2011;210(11):523-525.

22. Slaughter A, Katz RV, Grasso JE. Professional attitudes toward denture adhesives: a Delphi technique survey of academic prosthodontists. J Prosthet Dent 1999 Jul;82(1):80-89.
23. Stafford GD, Russel C. Efficiency of denture adhesives and their possible influence on microorganisms. J Dent Res 1971 Aug;50(1):832-836.

24. Coates AJ. Usage of denture adhesives. J Dent 2000 Feb;28(2):137-140.

25. Ozcan M, Kulak Y, Arikan A, Silahtar E. The attitude of complete denture wearers toward denture adhesives in Istanbul. J Oral Rehabil 2004 Feb;31(2):131-134.

26. Tarbet WJ, Grossman E. Observation of denture-supporting tissue during six months of denture adhesive wearing. J Am Dent Assoc 1980 Nov;101(5):789-791.

27. De Baat C, van't Hof M, van Zeghbroeck L, Ozcan M, Kalk W. An international multicenter study on the effectiveness of a denture adhesive in maxillary dentures using disposable gnathometers. Clin Oral Investig 2007;11(3):237-243.

28. Douglass CW, Shih A, Ostry L. Will there be a need for complete dentures in the United States in 2020. J Prosthet Dent 2002 Jan;87(1):5-8.

29. Emami E, Heydecke G, Rompré PH, de Grandmont P, Feine JS. Impact of implant support for mandibular dentures on satisfaction, oral and general health-related quality of life: a meta-analysis of randomized-controlled trials. Clin Oral Implants Res 2009 Jun;20(6):533-544. 